\title{
Onion yield under agroecological farming system using distinct irrigation depths and soil covers
}

\author{
Produtividade de cebola em sistema de cultivo agroecológico sob \\ distintas lâminas de irrigação e coberturas do solo
}

\author{
Eduardo Castro Ribeiro ${ }^{I}$ Daniel Fonseca de Carvalho ${ }^{\text {II }}$ \\ Lucas Antonio de Freitas Santos ${ }^{\text {III }}$ José Guilherme Marinho Guerra ${ }^{\text {IV }}$
}

\section{ABSTRACT}

The present study was carried out in order to evaluate the effects of irrigation depths applied through drip and presence/ absence of soil cover in onion yield, under agroecological farming. The experiment was conducted in Seropédica, RJ, Brazil, from May to September 2012. The experimental design was a randomized complete block with split-plot design with 10 treatments and 7 replications, characterized by the presence $(+S)$ and absence $(-S)$ of soil cover and five irrigation depths according to percentages of the crop evapotranspiration (ETc): 0, 22, 45, 75 and $100 \%(0$, $155,220.6,320.5$ and $372,7 \mathrm{~mm}$ in $+S$ condition and $0,145.5$, $207.6,285,351,4 \mathrm{~mm}$ in $-S$ condition). The irrigation influenced by second-order polynomial regression the total yield of bulbs, percentage distribution of bulbs in diameter classes and water use efficiency (WUE) in the $-S$ condition, and in the linear regression the WUE in $+S$ condition. The soil cover promoted an increase on the total bulb yield, WUE and the percentage of bulbs classified in classes of greater diameter.

Key words: water use efficiency, Allium cepa L., organic agriculture.

\section{RESUMO}

O presente estudo teve como objetivo avaliar os efeitos de lâminas de irrigação, aplicadas via gotejamento, e do uso de cobertura morta na produção de cebola em cultivo agroecológico. $O$ experimento foi conduzido em Seropédica, RJ, no periodo de Maio a Setembro de 2012. O delineamento experimental adotado foi em blocos completos casualizados com parcelas subdivididas, com 10 tratamentos e 7 repetições, caracterizados pela presença (CC) e ausência (SC) de cobertura do solo e por cinco lâminas de irrigação, relativas às porcentagens da evapotranspiração da cultura (ETc): 0, 22, 45, 75 e 100\% (0; 155; 220,6; 320,5 e 372,7mm na condição SC e 0; 145,5; 207,6; 285 e 351,4mm na condição CC). A irrigação influenciou, por meio da regressão polinomial de segunda ordem, as variáveis produtividade total de bulbos, distribuição do percentual de bulbos em classes de diâmetro e eficiência do uso da água (EUA) na condição $S C$ e, na regressão linear a EUA, na condição CC. A cobertura morta promoveu um incremento na produtividade total de bulbos, na eficiência do uso da água e no percentual de bulbos enquadrados nas classes de maior diâmetro.

Palavras-chave: eficiência do uso da água, Allium cepa L., agricultura orgânica.

\section{INTRODUCTION}

Onion (Allium cepa $\mathrm{L}$.) is considered the third vegetable in economic importance in Brazil (RESENDE \& COSTA, 2008) and worldwide (OLIVEIRA et al., 2013). It is the main activity for more than 60 thousand families in Brazil and is performed almost $100 \%$ under irrigation, except in the South region. The yields obtained by some producers in the States of São Paulo $\left(40 \mathrm{t} \mathrm{ha} \mathrm{h}^{-1}\right)$ and Minas Gerais (60t ha $\mathrm{h}^{-1}$ ) (MAROUELLI et al., 2005) have been well above the average yield obtained in Brazil (23.2t ha ${ }^{-1}$; IBGE, 2012).

All around the world, irrigated agriculture accounts for the production of more than $40 \%$ of food consumed, and production in irrigated areas is

\footnotetext{
IDiretoria de Agrotecnologia (DITEC), Secretaria do Desenvolvimento da Agricultura e Pecuária do Tocantins (SEAGRO), 77006-166, Palmas, TO, Brasil. E-mail: eduardo.ribeiro@seagro.to.gov.br. Corresponding author.

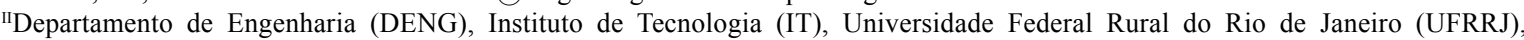
Seropédica, RJ, Brasil.

IIIInstituto de Agronomia (IA), Universidade Federal Rural do Rio de Janeiro (UFRRJ), Seropédica, RJ, Brasil.

${ }^{\mathrm{IV}}$ Laboratório de Solos, Embrapa Agrobiologia, Seropédica, RJ, Brasil
} 
2.5 times larger than in upland areas (MUKHERJI et al., 2009). However, $70 \%$ of the freshwater on earth are estimated to be used in the production of food, causing conflict between its various multiple uses (PAULINO et al., 2011). In this sense, irrigation systems, which are able to increase the efficiency of water use by plants and are based on the water needs of the crop, contribute to the rational use of scarce water resources in the planet (CARVALHO \& OLIVEIRA, 2012). In addition to a proper management of irrigation water, the use of crop residues in the form of soil cover is a widely used agricultural practice in organic production systems. Soil cover contributes to reduce natural water loss by evaporation on the soil surface, providing an increase in water use efficiency (CARVALHO et al., 2011).

Organic production of onion is feasible since the organic material is sufficient to provide all nutrients necessary for its growth, especially with cultivars that best suit this cropping system (COSTA et al., 2008).

Therefore, the aim of this study was to evaluate the effects of different irrigation depths applied by dripping and use of elephant grass straw as mulch on yield, classification of onion bulbs, and efficient use of water under agroecological farming.

\section{MATERIALS AND METHODS}

The study was conducted in 2012, at the Integrated System for Agroecological Production (SIPA, for Sistema Integrado de Produção Agroecológica) in Seropédica, RJ, Brazil. The climate in the region is Aw (Köppen classification), with average temperature of $24.5^{\circ} \mathrm{C}$ and average annual rainfall of $1213 \mathrm{~mm}$ (LIMA et al., 2012). The soil in the study area was classified as: moderate Red-Yellow Dystrophic Argisol A; Franco-sandy texture and gently rolling relief. Its chemical composition (layer: $0-0.15 \mathrm{~m}$ ) is as follows: $\mathrm{P}=0.2 \mathrm{cmolc} \mathrm{dm} \mathrm{dm}^{-3} ; \mathrm{K}^{+}=0.2 \mathrm{cmolc} \mathrm{dm}^{-3}$; $\mathrm{Ca}^{2+}=2.6 \mathrm{cmolc} \mathrm{dm}^{-3} ; \mathrm{Mg}^{2+}=0.89 \mathrm{cmolc} \mathrm{dm}^{-3} ; \mathrm{Al}^{3+}=$ $0.01 \mathrm{cmolc} \mathrm{dm}^{-3}$; bulk density $=1.37 \mathrm{~g} \mathrm{~cm}^{-3}$, and $\mathrm{pH}$ $\left(\mathrm{H}_{2} \mathrm{O}\right)=6.7$; (EMBRAPA, 2006).

The agro-climatic monitoring was carried out with information from an automatic meteorological station installed at SIPA. During the cycle, average values were recorded for global solar radiation $\left(14.6 \mathrm{MJ} \mathrm{m}^{2} \mathrm{~d}^{-1}\right)$, relative humidity $(72 \%)$, wind speed $\left(88.1 \mathrm{~km} \mathrm{~d}^{-1}\right)$, rainfall $(217.6 \mathrm{~mm})$, and daily temperature $\left(14.8-32.2^{\circ} \mathrm{C}\right)$.

This study adopted an experimental design in randomized complete block with split-plot design, 10 treatments and 7 replications, characterized by the presence $(+\mathrm{S})$ and absence $(-\mathrm{S})$ of soil cover (sub-plots), and five irrigation depths (plots), corresponding to $0\left(\mathrm{ID}_{0}\right), 22\left(\mathrm{ID}_{1}\right), 45\left(\mathrm{ID}_{2}\right), 75\left(\mathrm{ID}_{3}\right)$, and $100 \%\left(\mathrm{ID}_{4}\right)$ of crop evapotranspiration (ETc). At the end of the experiment, it was applied water in the total depths of $0,155,220.6,320.5$, and $372.7 \mathrm{~mm}$ in the $-\mathrm{S}$ condition and $0,145.5,207.6,285.0$, and $351.4 \mathrm{~mm}$ in the $+\mathrm{S}$ condition. In addition to the irrigation depth, the effective precipitation (Pef) was quantified, being considered as the precipitated water depth $(\mathrm{mm})$ that provided an increase in water content in the plots until the moisture correspond to field capacity (CARVALHO et al., 2011).

The irrigation system by dripping was employed. It was composed of two lateral lines per plot, and the wetted area percentage (WAP) varied in the range $50-100 \%$ according to the crop development. The irrigation management was carried out by monitoring soil water content with the time domain reflectometry (TDR) technique (SONCELA et al., 2013). The soil moisture was monitored in the sub-portion corresponding to the $\mathrm{L}_{4}$ depth, and the irrigation frequency of two days was adopted. The first and last irrigations were performed at 23 and 114 days after transplanting (DAT).

For a proper use of the TDR technique, a calibration was previously carried out in the study area as described by LIMA et al. (2012), generating the equation $\theta\left(\mathrm{cm}^{3} \mathrm{~cm}^{-3}\right)=0.015 \mathrm{~K}_{\mathrm{a}}-0.0223\left(\mathrm{R}^{2}=\right.$ $0.73)$. In the same process, the humidity value of $0.214 \mathrm{~cm}^{3} \mathrm{~cm}^{-3}$ was found, which corresponded to the field capacity for the layer of $0-0.15 \mathrm{~m}$. The readings of the apparent dielectric constant $\left(\mathrm{K}_{\mathrm{a}}\right)$ obtained with the TDR probes were performed immediately before irrigation, allowing to calculate the water depth to be applied to each irrigation in both soil cover conditions. Eight TDR probes were used at $7.5 \mathrm{~cm}$ depth (one per subplot; chosen at random), corresponding to $100 \%$ of ETc replacement depth in the $-\mathrm{S}(4)$ and $+\mathrm{S}$ conditions (4).

The soil cover was composed by the aerial portion, which was chopped and dried under the shadow of elephant grass Pennisetum purpureum Schum. cv. 'Cameron' $\left(2.5 \mathrm{~kg} \mathrm{~m}^{-2}\right.$ of dry matter), according to OLIVEIRA et al. (2008), and it was applied 22 DAT.

The 'Alfa Tropical' onion cultivar was sowed (16 Apr 2012) in 288-cell expanded polystyrene trays. Transplanting was performed (27 May) in sub-plots (width: 1.0m; length: $1.0 \mathrm{~m}$ ). Four planting lines were used (spacing: $0.25 \mathrm{~m}$ between lines; $0.1 \mathrm{~m}$ between plants). For evaluation, the plants in the central lines were considered useful. 
Of the total irrigations, the culture received $29.7 \mathrm{~mm}$ by sprinkler irrigation, during the period of establishment of seedlings after transplanting. In this period, the water depth was estimated by Class-A pan evaporation, using a crop coefficient $(\mathrm{Kc})$ of 1.0 (MAROUELLI et al., 2005).

The basic fertilization was performed with cattle manure (dosage: 25t ha-1) (CARVALHO et al., 2011). The topdressing fertilization was carried out with castor bean cake $\left(100 \mathrm{~kg} \mathrm{ha}^{-1} \mathrm{~N}\right)$, divided into two applications (30 and 50 DAT) (COSTA et al., 2008). The weed control was performed through manual weeding $(15,40$, and 70 DAT).

A level of damage was detected (27 DAT) for pale-sided cutworm (Agrotis ipsilon) and purple spot (Alternaria porri and Stemphylium vesicarium). Control of caterpillar was performed on the same day, with application of a 1\% Bacillus thuringiensis solution, and the control of purple stain was performed with weekly sprays of Bordeaux mixture, with addition of $0.1 \%$ mineral oil (MICHEREFF FILHO et al., 2009; SILVA, 2011).

Plants were harvested 124 DAT and kept in the shade for the curing period (15 days). It was then possible to assess the total yield of bulbs and their percent distribution in different classes of diameter, according to CEAGESP (2001) $\left(\mathrm{C}_{1}\right.$ : non-commercial bulbs $\leq 35 \mathrm{~mm} ; \mathrm{C}_{2}: 35-50 \mathrm{~mm} ; \mathrm{C}_{3}: 50-60 \mathrm{~mm} ; \mathrm{C}_{4}: 60-$ $70 \mathrm{~mm}$; and $\left.\mathrm{C}_{5}: 70-90 \mathrm{~mm}\right)$. Then, water use efficiency (WUE) was evaluated as being the ratio between the production obtained and water depth applied (irrigation in the establishment period + effective precipitation + irrigation in the treatments).

Data were submitted to variance and regression analysis for the irrigation depth factor, and the Tukey test for the soil cover factor (comparison between averages). The System for Statistical analyzes (SAEG 9.1) computer program was used.

\section{RESULTS AND DISCUSSION}

The temperature values (daily averages: $14.8-32.2^{\circ} \mathrm{C}$ ) indicated that the crop cycle occurred in conditions favorable to a good development of the crop. The most critical values of minimum $\left(10.8^{\circ} \mathrm{C}\right.$; $26 \mathrm{Sep})$ and maximum $\left(40.9^{\circ} \mathrm{C} ; 19 \mathrm{Sep}\right)$ temperature occurred in the bulb maturation phase, when the temperature is supposed to have a smaller influence on the production variables. According to RESENDE et al. (2007), temperatures in the range $15.5-21.1^{\circ} \mathrm{C}$ allow formation of the best bulbs and a greater production. Figure 1 shows that the accumulated precipitation was $217.6 \mathrm{~mm}$ during the period of growth in the field (124 days), with daily depths reaching 47.0 (22 Jun) and 40.0mm (25 Sept). Despite these values, $64.7 \mathrm{~mm}$ (-S condition) and $58.5 \mathrm{~mm}(+\mathrm{S}$ condition) were recorded as effective depths.

Figure 1 shows the irrigation depths by dripping for both soil cover conditions. For treatment L4 (100\% of ETc), the depths totaled 372.7 and

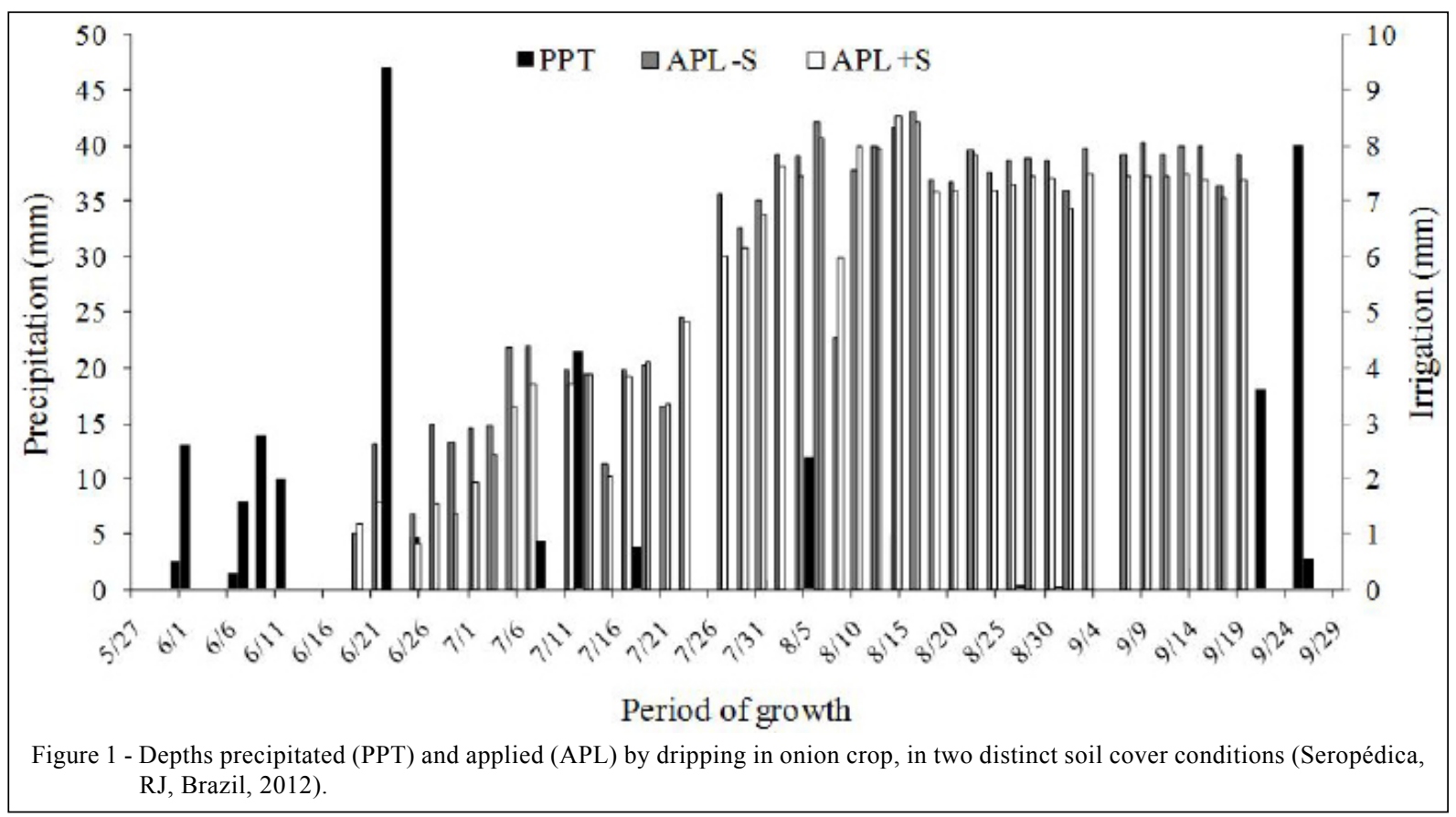

Ciência Rural, v.46, n.5, mai, 2016. 
$351.4 \mathrm{~mm}$ under the conditions of absence and presence of soil cover, respectively.

According to the analysis of variance, the effects ( $\mathrm{P}<5 \%)$ of total yield of bulbs (TYB) and water use efficiency (WUE) were significant (Figure 2), but interaction in relation to the irrigation depth and soil cover factors were not observed. In view of the significant response $(\mathrm{P}<5 \%)$ among the mean values of TYB and different depths (L) applied, models of second order polynomial regression were adjusted to the different cover conditions: $\mathrm{TYB}_{-\mathrm{S}}=-0.0004 \mathrm{~L}^{2}+$ $0.29 \mathrm{~L}-13.15$ and $\mathrm{TYB}_{+\mathrm{S}}=-0.0004 \mathrm{~L}^{2}+0.28 \mathrm{~L}-3.48$.

For depth L4, total yield of bulbs (TYB) of $39.9(-\mathrm{S})$ and $52.1(+\mathrm{S}) \mathrm{t} \mathrm{ha}^{-1}$ were obtained

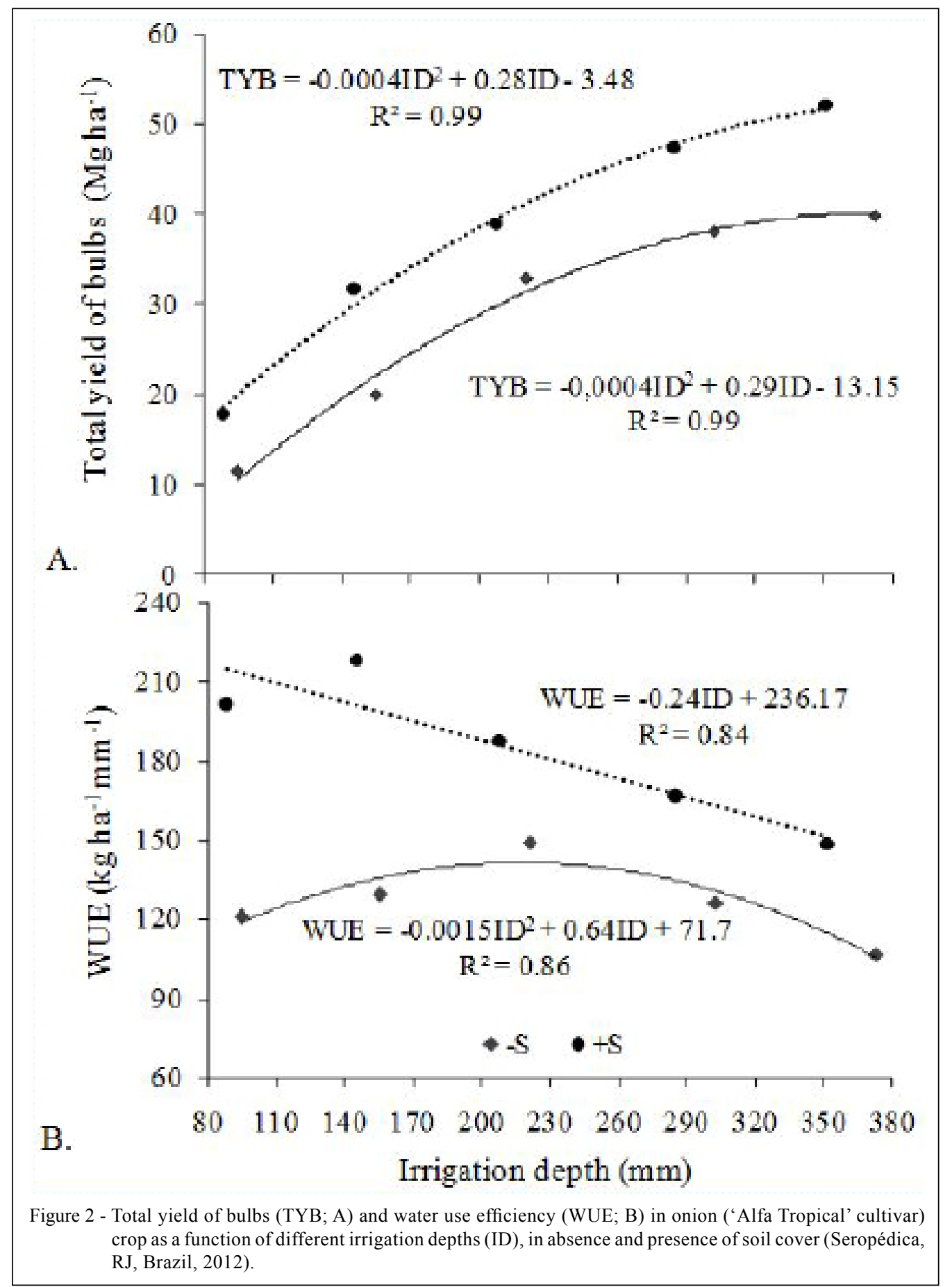

Ciência Rural, v.46, n.5, mai, 2016. 
(Figure 2A), surpassing the national average $(23.2 \mathrm{t}$ $\mathrm{ha}^{-1}$; IBGE, 2012) in $71.7 \%(-\mathrm{S})$ and $124.2 \%(+\mathrm{S})$. These data are compatible with those reported by OLIVEIRA et al. (2013), who obtained total yields ranging from $43.2 \mathrm{tha}^{-1}$ (irrigation performed by using Kc values proposed by MAROUELLI et al. (2005), and ETo obtained by the Class-A pan) to $51.7 \mathrm{tha}^{-1}$ (irrigation performed with basis on ETc data obtained by evapotranspirometer).

The maximum value for TYB, obtained by applying the greatest water depth $(100 \% \mathrm{Tc})$, can be explained by a higher water comfort to which the culture is subjected at this level of irrigation, which keeps the soil water close to field capacity. In this condition, the culture maintains the transpiration rate nearer to the maximum favorable to its development, and consequently, to a higher yield (RAJPUT \& PATEL, 2006).

Analysis of variance indicated that the results of WUE as a function of irrigation depths were significant $(\mathrm{P}<5 \%)$. Regression analysis was performed by adjusting the second-order polynomial model $(\mathrm{P}<6 \%)$ to the data obtained in the $-\mathrm{S}$ condition $\left(\right.$ WUE $\left._{-}=-0.0015 \mathrm{~L}^{2}+0.64 \mathrm{~L}+71.70\right)$ and the linear model $(\mathrm{P}<5 \%)$ to the data obtained in the $+\mathrm{S}$ condition $\left(\mathrm{WUE}_{+\mathrm{S}}=-0.24 \mathrm{~L}+236.17\right)$ (Figure $\left.2 \mathrm{~B}\right)$. This equation shows that $1-\mathrm{mm}$ increase in the irrigation depth causes a $0.24 \mathrm{~kg} \mathrm{ha}^{-1}$ decrease in $\mathrm{WUE}_{+\mathrm{S}}$, indicating that the increase in yield is proportionally lower than the increase in the irrigation depth and effective rainfall. In the $+\mathrm{S}$ condition, the maximum value for WUE occurred in the treatment associated with the control depth (without irrigation). Some studies conducted with other vegetables also show that WUE increases with a decrease in water depth applied and/or increase in soil water tension (SILVA, 2011).

For the -S condition (Figure 2B), according to polynomial model, an increase was observed in WUE as a function of the increase in the irrigation depths, up to $214.4 \mathrm{~mm}$, corresponding to $57.5 \%$ of ETc. At this point, the maximum WUE values $\left(140.7 \mathrm{~kg} \mathrm{ha}^{-1} \mathrm{~mm}^{-1}\right)$ were obtained. Then, the values decreased until the highest depth $(372.7 \mathrm{~mm})$ applied, for which WUE $=107.1 \mathrm{~kg} \mathrm{ha}^{-1} \mathrm{~mm}^{-1}$ was estimated. From the point of maximum WUE on, it usually decreases with increasing irrigation. According to KUMAR et al. (2007), the percent increase in yield beyond this point is usually smaller than that by increase in the irrigation depth.

In general, the smallest depths provided higher percentages of bulbs with smaller diameter (Figure 3). Depth $\mathrm{ID}_{0}$ provided $62.2(-\mathrm{S})$ and 39.8\% $(+\mathrm{S})$ of bulbs classified as $\mathrm{C}_{1}$ (without commercial value) and $97.8(-\mathrm{S})$ and $90.8 \%(+\mathrm{S})$ of bulbs classified in the sum $\mathrm{C}_{1}$ plus $\mathrm{C}_{2}$. The higher irrigation depth (L4) applied in this study, with replacement of the ETc $(100 \%)$, provided a higher percentage of bulbs distributed in the $\mathrm{C}_{3}(26.8$ and $31.8 \%), \mathrm{C}_{4}$ (15.9 and

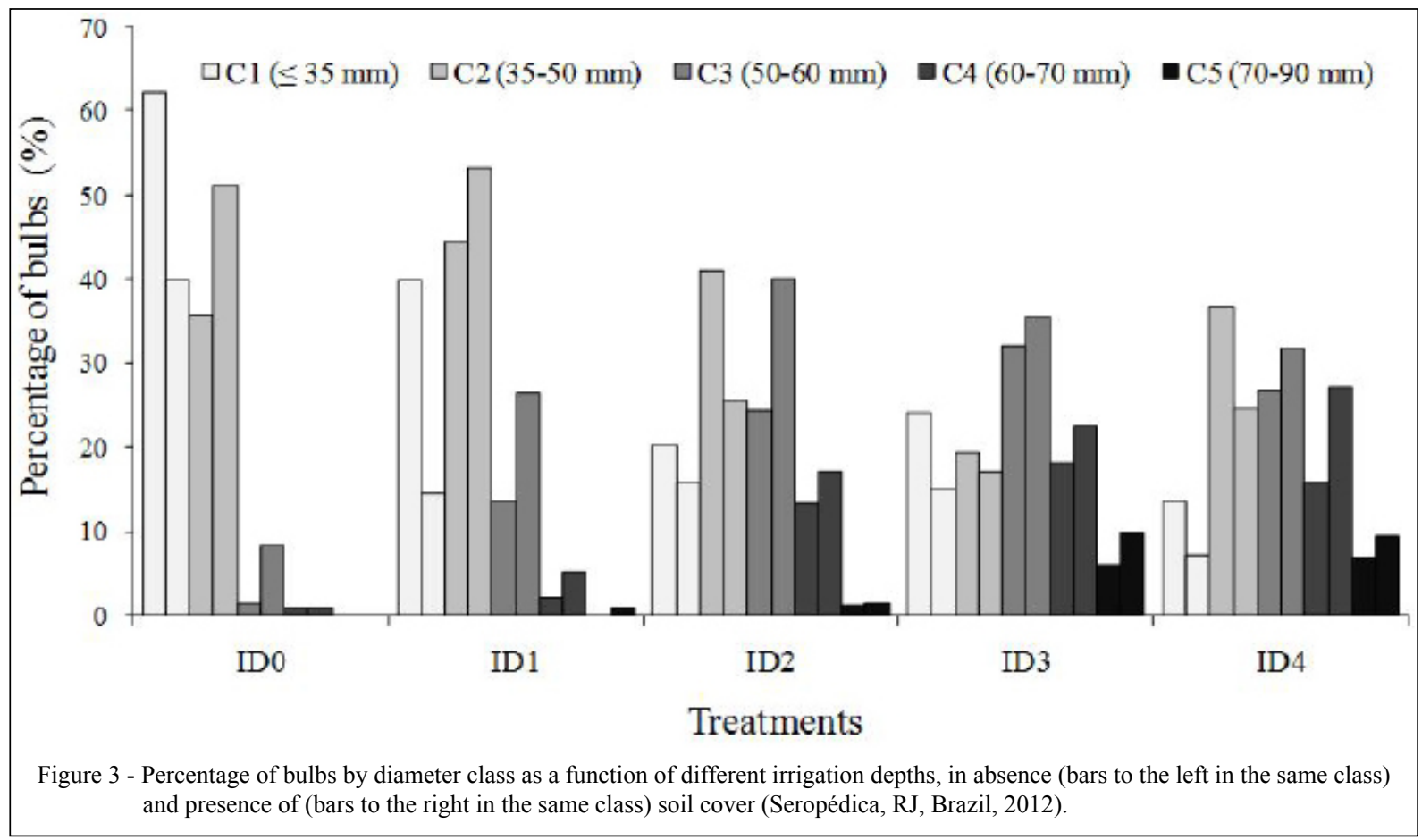

Ciência Rural, v.46, n.5, mai, 2016. 
$27.1 \%$ ), and $\mathrm{C}_{5}(7.0$ and $9.5 \%$ ) classes for the $-\mathrm{S}$ and $+\mathrm{S}$ conditions, respectively. This result is related to a higher water availability, which provided maintenance of soil moisture in values next to the values of field capacity and favored the formation of larger bulbs.

A behavior similar to that of the irrigation factor was also observed in soil cover factor relative to the distribution of bulb diameters. As compared to the $-\mathrm{S}$ condition, the $+\mathrm{S}$ condition reduced the percentage of bulbs with smaller diameter $\left(\mathrm{C}_{1}\right.$ and $\mathrm{C}_{2}$ ) and increased the percentage of bulbs with larger diameter $\left(\mathrm{C}_{3}, \mathrm{C}_{4}\right.$, and $\left.\mathrm{C}_{5}\right)$. This result was attributed to the beneficial effects of soil cover (such as reduction in both weed competition and water evaporation through the soil surface), which favored a higher level of soil moisture in the $+\mathrm{S}$ condition.

Presence of soil cover influenced the TYB and WUE variables, and the values for $+\mathrm{S}$ condition were higher than those for the -S condition (Table 1). In the $+\mathrm{S}$ condition, gains were observed in the WUE $(30.7 \%)$ and TYB $(24.2 \%)$ variables, in relation to the $-\mathrm{S}$ condition. This result may be related to the interaction between the beneficial effects provided by the presence of straw as soil cover. According to OLIVEIRA et al. (2008), LIMA et al. (2012), and CARVALHO et al. (2011), presence of cover promotes a reduction in water evaporation from the soil surface, maintenance of moisture in the surface layers for a longer time, and reduction in both temperature and soil exposure to direct impact of raindrops. Therefore, there is a reduction in the water depth to be applied, besides other important aspects such as reduction in weed competition and supply of nutrients to the soil.

\section{CONCLUSION}

Use of mulch in agro-ecological farming raises the TYB and WUE levels. The irrigated onion crop provides a higher TYB associated with greater water depth $(100 \%$ of ETc), indicating that irrigation

Table 1 - Average of total yield of bulbs ('Alfa Tropical' cultivar) and water use efficiency as a function of two distinct soil cover conditions (Seropédica, RJ, Brazil, 2012).

\begin{tabular}{lll}
\hline Cover factor & TYB $\left(\mathrm{Mg} \mathrm{ha}^{-1}\right)$ & WUE $\left(\mathrm{kg} \mathrm{ha}^{-1} \mathrm{~mm}^{-1}\right)$ \\
\hline Absence $(-\mathrm{S})$ & $28.5 \mathrm{~b}$ & $126.7 \mathrm{~b}$ \\
Presence $(+\mathrm{S})$ & $37.6 \mathrm{a}$ & $184.3 \mathrm{a}$ \\
\hline
\end{tabular}

Equal letters indicate that the values in that line are not different by the Tukey test ( $5 \%$ probability). is a viable technique in the existing edaphoclimatic conditions in Seropédica, RJ, Brazil. The soil cover increases water efficiency in the $+\mathrm{S}$ condition, and WUE varies linearly with increase in the depth applied. Irrigation and soil cover increase the percentage of bulbs with diameter greater than $50 \mathrm{~mm}$.

\section{REFERENCES}

CARVALHO, D.F. et al. Manejo da irrigação associada a coberturas mortas vegetais no cultivo orgânico da beterraba. Engenharia Agrícola, v.31, p.269-277, 2011. Available from: <http://dx.doi. org/10.1590/S0100-69162011000200007>. Accessed: Apr. 12, 2012. doi: 10.1590/S0100-69162011000200007.

CARVALHO, D.F.; OLIVERIA, L.F.C. Planejamento e manejo da água na agricultura irrigada. Viçosa, MG: UFV, 2012. 240p.

COMPANHIA DE ENTREPOSTOS E ARMAZÉNS GERAIS DE SÃO PAULO (CEAGESP). Classificação da cebola (Allium cepa L.). Available from: <http://www.hortibrasil.org.br/jnw/images/ stories/folders/cebola.pdf $>$. Accessed: Sept. 05, 2012.

COSTA, N. D. et al. Desempenho de cultivares de cebola em cultivo orgânico e tipos de solo no Vale do São Francisco. Horticultura Brasileira, v.26, n.4, p.476-480, 2008. Available from: <http:// dx.doi.org/10.1590/S0102-05362008000400010>. Accessed: May 10, 2012. doi: 10.1590/S0102-05362008000400010.

EMPRESA BRASILEIRA DE PESQUISA AGROPECUÁRIA (EMBRAPA). Sistema brasileiro de classificação de solos. 2.ed. Brasília: Embrapa Produção de informação; Rio de Janeiro: Embrapa Solos, 2006. 312p

INSTITUTO BRASILEIRO DE GEOGRAFIA E ESTATÍSTICA (IBGE). Confronto das safras (Rendimento médio) de 2011 e 2012 - Brasil - Março 2012. Available from: <http://www. ibge.gov.br/home/estatistica/indicadores/agropecuaria/lspa/ 1spa_201203_3.shtm>. Accessed: May 02, 2012.

KUMAR, S. et al. Response of onion (Allium cepa L.) to different levels of irrigation water. Agricultural Water Management, v.89, p.161-166, 2007. Available from: <http://dx.doi.org/10.1016/j. agwat.2007.01.003>. Accessed: Aug. 10, 2012. doi: 10.1016/j. agwat.2007.01.003.

LIMA, M.E. et al. Desempenho do cultivo da berinjela em plantio direto submetida a diferentes lâminas de irrigação. Revista Brasileira de Engenharia Agrícola e Ambiental, v.16, n.6, p.604-610, 2012. Available from: <http://www.scielo.br/pdf/rbeaa/ v16n6/v16n06a03.pdf >. Accessed: Apr. 13, 2012.

MAROUELLI, W.A. et al. Irrigação da cultura de cebola. Brasília: Embrapa Hortaliças, 2005. 17p. (Circular técnica n.37). Available from: <http://www.cnph.embrapa.br/paginas/ serie_documentos/publicacoes2005/ct_37.pdf $>$. Accessed: May 10, 2012.

MUKHERJI, A. et al. Revitalizing Asia's irrigation: to sustainably meet tomorrow's food needs. Colombo, Sri Lanka: International Water Management Institute; Rome, Italy: Food and Agriculture Organization of the United Nations, 2009. 38p. Available from: $<$ http://www.adb.org/sites/default/files/publication/29252/ revitalizing-asia-irrigation.pdf $>$. Accessed: Feb. 05, 2014. 
MICHEREFF FILHO, M. et al. Recomendações para o controle de pragas em hortas urbanas. Brasília, DF: EMBRAPA, 2009. 11p. (Circular Técnica n. 80). Available from: <http://www.cnph.embrapa. br/paginas/bbeletronica/2009/ct/ct_80.pdf $>$. Accessed: May 24, 2012.

OLIVEIRA F.F. et al. Avaliação de coberturas mortas em cultura de alface sob manejo orgânico. Horticultura Brasileira, v.26, n.2, p.216-220, 2008. Available from: < http://dx.doi.org/10.1590/ S0102-05362008000200017>. Accessed: May 09, 2012. doi: $10.1590 / \mathrm{S} 0102-05362008000200017$.

OLIVEIRA, G.M. et al. Coeficiente de cultura e produtividade da cebola submetida a diferentes lâminas de irrigação. Revista Brasileira de Engenharia Agrícola e Ambiental, v.17, n.9, p.969-974, 2013. Available from: <http://dx.doi.org/10.1590/ S1415-43662013000900009>. Accessed: May 12, 2012. doi: $10.1590 / \mathrm{S} 1415-43662013000900009$.

PAULINO, J. et al. Situação da agricultura irrigada no Brasil de acordo com o censo agropecuário 2006. Irriga, v.16, n.2, p.163-176, 2011 Available from: <http://dx.doi.org/10.15809/irriga.2011v16n2p163>. Accessed: Apr. 05, 2012. doi: 10.15809/irriga.2011v16n2p163.

RAJPUT, T.B.S.; PATEL, N. Water and nitrate movement in drip-irrigated onion under fertigation and irrigation treatments. Agricultural Water Management, v.79, p.293-311, 2006 Available from: <http://dx.doi.org/10.1016/j.agwat.2005.03.009>. Accessed: May 20, 2012. doi: 10.1016/j.agwat.2005.03.009.
RESENDE, G.M.; COSTA, N.D. Épocas de plantio e doses de nitrogênio e potássio na produtividade e armazenamento da cebola. Pesquisa Agropecuária Brasileira, v.43, n.2, p.221226, 2008. Available from: <http://dx.doi.org/10.1590/S0100204X2008000200010>. Accessed: Apr. 15, 2012. doi: 10.1590/ S0100-204X2008000200010.

RESENDE, G.M. et al. Cultivo da cebola no Nordeste. Petrolina: Embrapa Semi-Árido, 2007. Available from: $<$ http://sistemasdeproducao.cnptia.embrapa.br/ FontesHTML/Cebola/CultivoCebolaNordeste/clima.htm>. Accessed: May 15, 2012.

SILVA, D.G. Necessidade hídrica e produtividade da batata (Solanum tuberosum L.) sob diferentes lâminas de irrigação em cultivo agroecológico. 2011. 82f. Dissertação (Mestrado em Fitotecnia) - Curso de Pós-graduação em Fitotecnia, Universidade Federal Rural do Rio de Janeiro, RJ. Available from: <http://cursos.ufrrj.br/posgraduacao/ppgf/files/2013/08/ Disserta\%C3\%A7\%C3\%A3o-PPGF-Dione-Galv\%C3\%A3oda-Silva.pdf $>$. Accessed: Jun. 10, 2012.

SONCELA, R. et al. Construction and calibration of TDR probes for volumetric water content estimation in a Distroferric Red Latosol. Engenharia Agrícola, v.33, n.5, p.919-928, 2013. Available from: <http://dx.doi.org/10.1590/ S0100-69162013000500004>. Accessed: Apr. 25, 2014. doi: 10.1590/S0100-69162013000500004. 